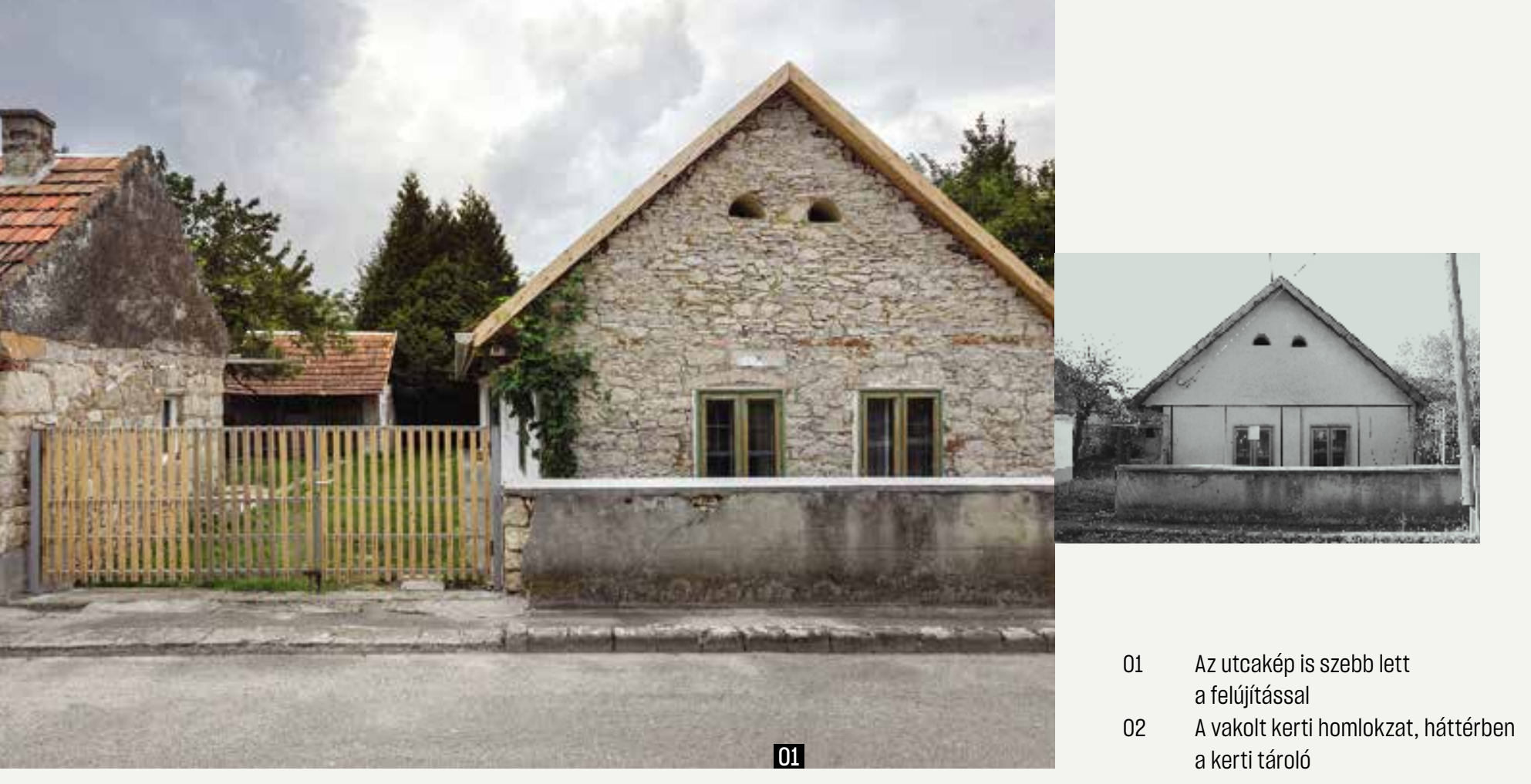

\title{
CSERÉPFALUI SZERELEM
}

\section{CSALÁDI HÁZ FELÚJÍTÁSA |}

BORSOD MEGYE
ÉPÍTÉSZ |

Fajesák Dénes, Fábián Gábor DLA (Arkt Építész Stúdió)

\author{
_Magyarországon a vidék \\ lassan kiüresedik, a fiatalok \\ elvándorolnak, az idősek \\ meghalnak. Megyénként \\ több ezer üres lakóház \\ marad vissza bús hírnökként, \\ hogy volt időszak, amikor \\ népesebbek voltak falvaink. \\ Házaink a történelmünk és \\ a vidék identitásának részét \\ képezik, érdemes foglalkozni \\ velük, és lehetőség szerint \\ menteni őket. Egyik \\ fenntartható megoldás \\ a cserépfalui beavatkozás.
}

STATIKA: Madaras Koppány | ÉPÜLETGÉPÉSZET: Molnár Gábor (tervezés és kivitelezés) | ÉPÜLETVILLAMOSSÁG: Bóta Péter tervező, Medve Tamás kivitelező | FAANYAGVÉDELMI SZAKMÉRNÖK: Szörényi Gábor | GEODÉZIA: Fegyverneki László | KŐMŰVESMUNKÁK: Zay Zoltán, Csepregi Sándor, Németh György és csapataik | ÁCSMUNKÁK: Juhász Patrik | FESTŐ: Nagy István | HOMLOKZATI FESTÉS: Pap Péter | BURKOLÁS: Melkó Zsolt | NYÍLÁSZÁRÓK, BÚTOROK: Stregova Dominik | HOMOKFÚVÁS: Dongó László | 


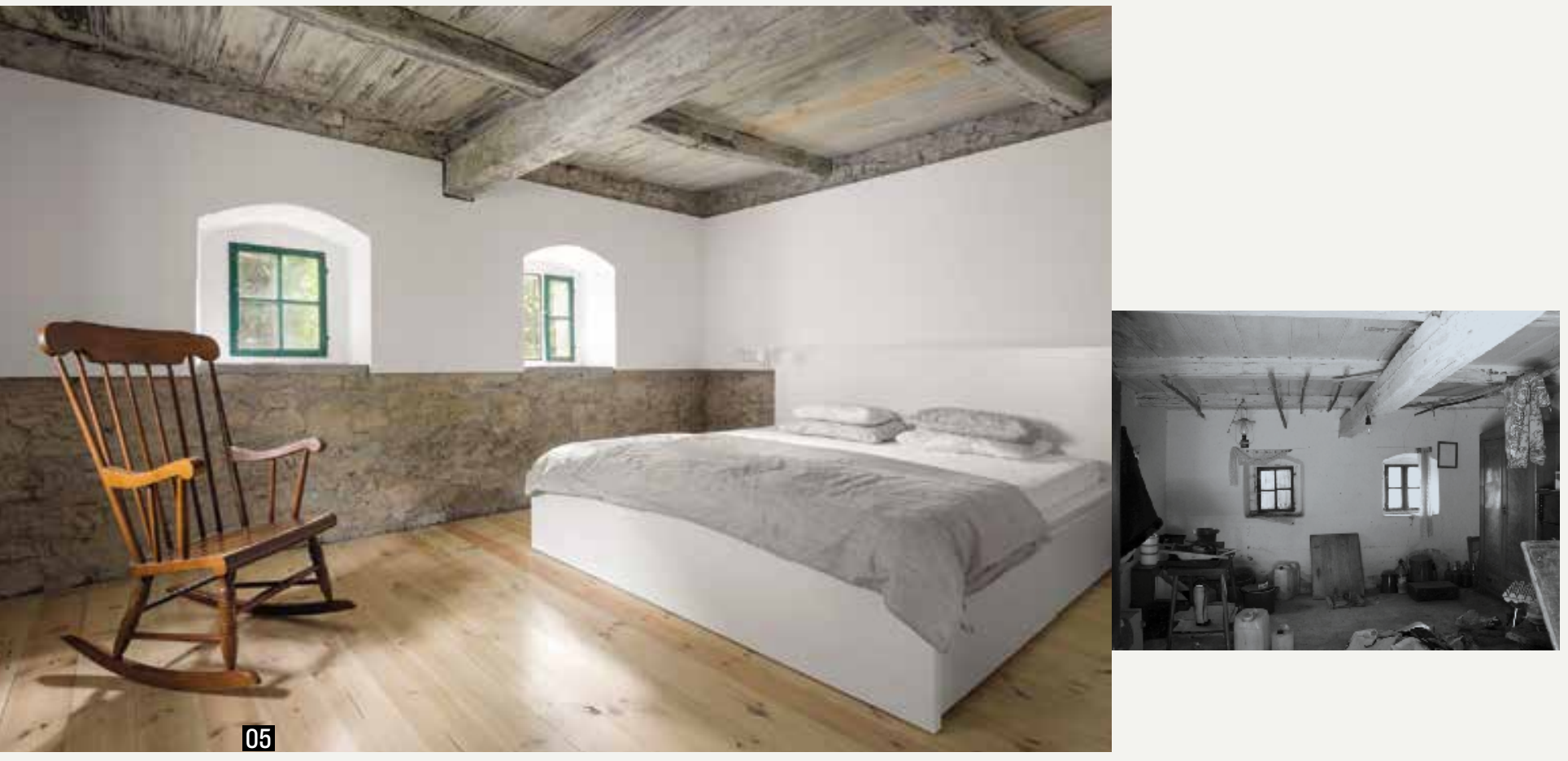

üvegtábla biztosítja a maximális kilátást az udvarra. A színek is koncepcionálisan lettek meghatározva. Az eredeti zöld szín maradt a régi nyílászárók színe, az újak középszürke színt (felületvédelmet) kaptak. Az új bútorok, beltéri ajtók fehérek vagy natúr fából készültek. A régi bútorok, kiegészítők jellemzően pirosak. A világítás kialakítása a ház egyszerüségét hivatott erősíteni funkcionális és egyszerű megoldásokkal. A ház újragondolásának elve: a kevesebb több. [3]

— 2020 januárjában Heves megye I2I darab, 3500 fős és az alatti létszámú településéhez juttattam el a következő adatszolgáltatási kérdésemet: hány darab üresen álló lakóépület, illetve hány darab közművel rendelkező építési telek található a területükön?

65 településről érkezett vissza adat, miszerint 3485 üresen álló lakóépület és 2215, lakóépület építésére alkalmas közművesített telek áll rendelkezésre.

_ Véleményem szerint Heves megyében a I2I településen megközelítőleg 6500-7000 üresen álló lakóház és 4000-nél is több építési telek kallódhat. Úgy gondolom, hogy ezek a számok jelentősnek mondhatóak. Félő, hogy a népességfogyással fordítottan arányosan ezek a számok tovább nőnek. Éppen ezért nagyon fontosnak tartom, hogy foglalkozzunk a kérdéssel, és megoldási javaslatot, alternatívákat kínáljunk a településeknek.

A cserépfalui példa egy lehetőség, amely müködőképes modellt biztosíthat hasonló értékek gyors, hatékony és költségtakarékos mentésére. Bízom benne, hogy lesznek követői, vagy teljesen más vonalon, de alternatívái. 


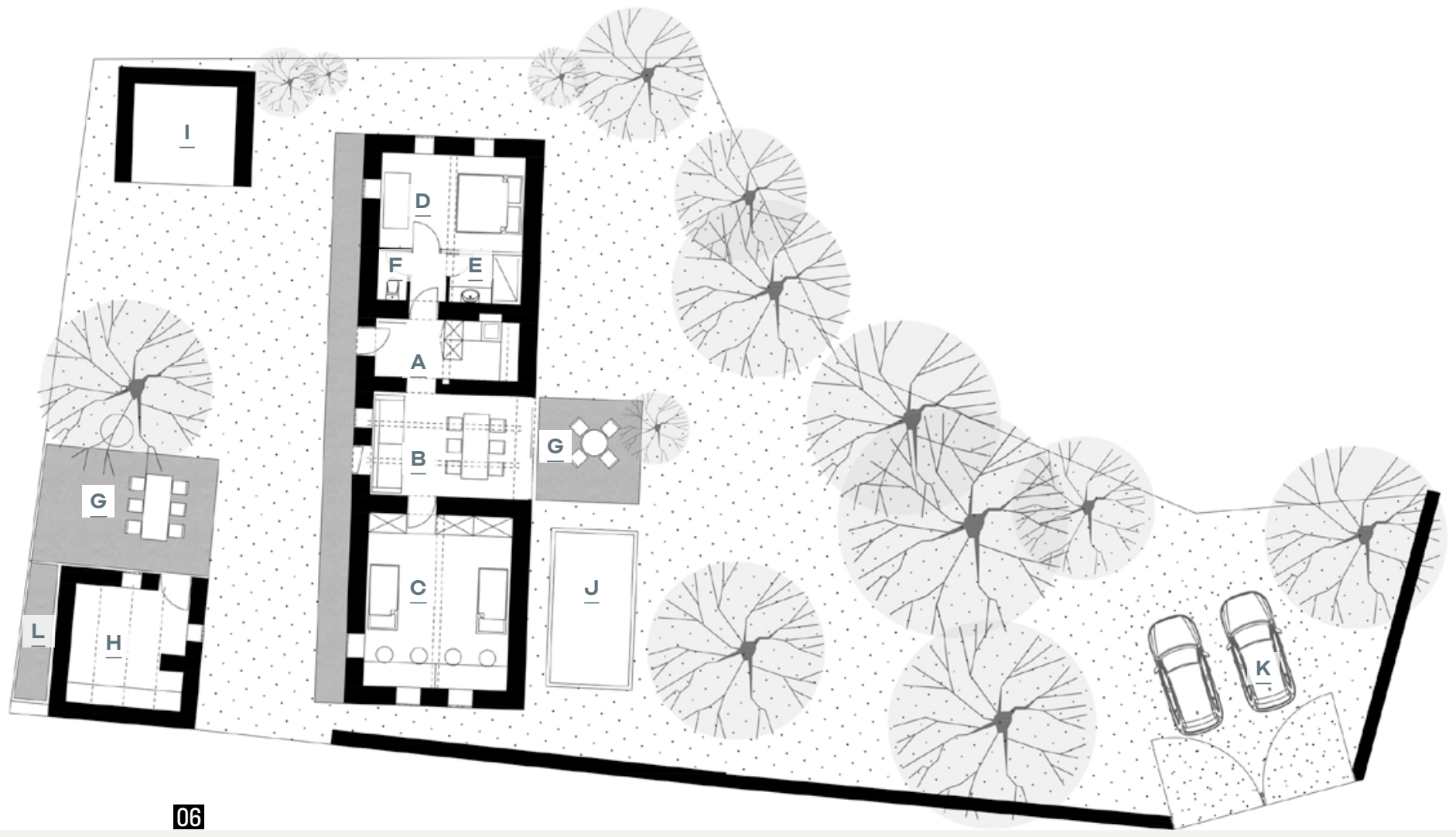

\begin{tabular}{l|l} 
A & Elötér + konyha \\
B & Étkező + nappali \\
C & Gyerekszoba \\
D & Szülői szoba \\
E & Fürdő \\
F & WC
\end{tabular}

G | Terasz

H | Nyárikonyha

I Kertitároló

$\checkmark$ Veteményes

K | Kocsibeálló

L | Szelektív hulladékgyưjtő

IRODALOM / REFERENCES

[1] Serdült, Szilvia - Vigné Cseh, Magdolna: Heves megye számokban, KSH, 2014, pp 4-5.

[2] Román, Róbert: „Fejlődési tendenciák az állami tulajdonú vállalkozások szabályozása terén, különös tekintettel régiónkénti megjelenésére”, Acta Oeconomica, Eszterházy Károly Főiskola, Eger 2007, pp 233-247.

[3] Timon, Kálmán: „Az egyszerűség az épitészetben - Építészkongresszus kilencedszer”, Metszet, Vol 3 (2012), № 2, pp 74-77. 


\section{ABSTRACTS}

\section{CSANÁDY, Pál: BUILT BIOPHILIA HYPOTHESIS}

Citation: Metszet, Vol 11, No 2 (2020), pp 14-21, DOI: 10.33268/Met.2020.2.1

METRODOM PANORÁMA RESIDENTIAL PARK, BUDAPEST, HUNGARY | Architect: Zsolt HAJNAL AND Péter KENDELÉNYI

To date the majority of newly built apartments in Hungary have given little consideration to the occupants' connection to the outside world, nature especially. This development hopes to increase the ratio of green areas throughout. Parkland, rooftop gardens and balconies with dedicated planting boxes will hel freshen up the environment. Noticeably one of the braver moves will be the planting of trees on alternate level balconies. Hopefully this project will satisfy the human need for contact with nature.

\section{SZABÓ, Julianna - BABOS, Annamária: NEW COMMUNAL CONDOMINIUMS IN VIENNA}

Citation: Metszet, Vol 11, No 2 (2020), pp 22-25, DOI: 10.33268/Met.2020.2.2

Architect: URBAN DEVELOPMENT

For nearly a hundred years Vienna as a municipality has been active in developing a strong urban housing policy. These policies have expanded from the limitations providing purely housing to encompass public spaces and integrated living and working environments. The ideas behind communal condominium development have stepped outside of the more convention build for profit realm into a truly active form of client investment and participation. The true needs of a city's occupants being valued as part of the urban makeup.

\section{BABOS, Annamária - SZABÓ, Julianna: CONNECTION POSSIBILITIES: CO-HOUSING IN A NEW RESIDENTIAL DISTRICT}

Citation: Metszet, Vol 11, No 2 (2020), pp 26-29, DOI: 10.33268/Met.2020.2.3

\section{GLEIS 21, SONNWENDVIERTEL, VIENNA, AUSTRIA | Architects: Markus ILKER}

Former railway land in Vienna has been redeveloped to create the new district of Sonnwendviertel, where Gleis 21 can be found. The name of this project translates as Platform 21, the only real link to the area's former function and identity. This communal development provides for housing, workplaces and social activities: conceived and developed by an association of occupiers this co-housing building even crosses boundaries into the virtual sphere having its own website to share ideas. From a practical aspect the division walls are non-structural allowing for future changes as the building moves through time, expansion and contraction of families for example.

\section{BABOS, Annamária - SZABÓ, Julianna: A LITTLE BIT OF EVERYTHING: CO-HOUSING, AS A MARKET?}

Citation: Metszet, Vol 11, No 2 (2020), pp 30-35, DOI: 10.33268/Met.2020.2.4

WOHNEN IM GRÜNEM MARKT, SONNWENDVIERTEL, VIENNA, AUSTRIA | Architects: SANDBICHLER ARCHITEKTEN

Sonnwendviertel district provides for many new types of co-housing. This example has been developed as its name suggests, above a marketplace, with the intention to provide shared facilities, community spaces and commercial activities. Developed as two volumes linked by a common staircase "scala" which also functions as a community theatre, cinema or gallery as needs require. Creativity being a key factor in the communal vision.

\section{SZABÓ, Julianna - BABOS, Annamária: INVISIBLE IDENTITY}

Citation: Metszet, Vol 11, No 2 (2020), pp 36-41, DOI: 10.33268/Met.2020.2.5

CO-HOUSING QUE(E)RBAU, SEESTADT, VIENNA, AUSTRIA | Architects: Clemens KIRSCH

On the outskirts of Seestadt a totally new

form of co-housing can be found - the

Que(e)rbau project. This is not merely an

experiment in property development or urban identity making, this is a home for people who are openly members of the "Queer" community or identity, lesbian, gay, bi, trans, inter. Architecturally this co-housing project can be seen as an equal amongst its type, functionally the ideas of community are upheld and socially it is not exclusive, the openness is extended towards everyone.

\section{PETHŐ, László: FORTY-PLUS ON A FORTY-MINUS}

Citation: Metszet, Vol 11, No 2 (2020), pp 42-45, DOI: 10.33268/Met.2020.2.6

FAMILY HOME, KŐSZEG, HUNGARY | Architects: Gábor VÖRÖS

Following the successful competition for younger architects in Hungary, FFF (Young in Black and White) architect Gábor Vörös has continued to work along the lines of something "MEANINGLESS" to say. Otherwise architects tend to have too much to say which is usually non-productive and to achieve a clearly defined modern family commentary. Be concise and concentrate on spatial arrangement, proportions and logical thinking.

\section{FAJCSÁK, Dénes: CSERÉPFALU LOVE}

Citation: Metszet, Vol 11, No 2 (2020), pp 46-51, DOI: 10.33268/Met.2020.2.7

FAMILY HOME REFURBISHMENT, CSERÉPFALU, HUNGARY | Architects: Dénes FAJCSÁK and Gábor FÁBIÁN DLA

Considering the large volume of unoccupied family homes in Hungary this project demonstrates how the traditional village cottage might be refurbished as an alternative to the trend for demolition and redevelopment of sites. The existing building type usually has a rational structure and arrangement of internal spaces which suggest the same approach be applied to any refurbishment work: keep it simple, work with local materials and employ local labour to do so. The result speaks for itself, whilst offering an example of the way forwards. 